\title{
KENAPA SESEORANG MELAKUKAN MANIPULASI LAPORAN KEUANGAN?: STUDI DENGAN PENDEKATAN SKENARIO KASUS DILEMA ETIKA
}

\author{
Hafiez Sofyani \\ Program Studi Akuntansi, Universitas Muhammadiyah Yogyakarta \\ Email: hafiez.sofyani@umy.ac.id \\ Nadia Rahma \\ Program Studi Ekonomi Islam, Universitas Islam Indonesia
}

\begin{abstract}
This study aims to identify the reasons why individu wants or does not to manipulates the financial statements. The design of this study refer to ethical dilemma scenarios developed by Sofyani and Pramita (2014). The samples are students of accounting from one university in Yogyakarta, which has joined in financial accounting and taxation courses. Data was analyzed using thematic deductive analysis approach (Braun and Clarke, 2006). The study find that the majority of students who want to manipulate the financial statements due to the reason that the manipulation did not force the legislation. While the majority of students who refuse the manipulation of financial statements reasoned that it violates religion obligation, because there is an element of falsehood. The results of this study can be used as the basis to develop further study with a broader scope, such as with survey approach.
\end{abstract}

\section{Keywords: Manipulation of Financial Statements; Ethical Dilemma} Scenarios; Legislation; Religioun Obligation

\section{PENDAHULUAN}

Kecurangan dalam praktik pelaporan keuangan merupakan masalah krusial dan sensitive di kalangan profesi akuntansi. Pasalnya, kecurangan yang dilakukan oleh seorang akuntan, dapat berdampak signifikan pada perekonomian, bahkan secara mikro. Sebagai contoh, praktik manipulasi laporan keuangan Yunani yang menggambarkan posisi keuangan Negara dalam keadaan aman dan stabil, namun faktanya adalah berkebalikan, pada akhirnya memicu terjadi kebangkrutan pada Negara tersebut. Devisa Yunani dianggap defisit dan tidak pantas masuk dalam zona Euro. Akhir dari drama tersebut adalah melemahnya perekonomian Yunani yang berdampak pada daya beli masyarakat yang melemah, sehingga memicu pergolakan social di Negara tersebut. Paparan di atas menunnjukkan betapa akuntan memiliki peran yang sangat penting dalam suatu perjalanan ekonomi suatu negara (Majalah Akuntan Indonesia, 2015).

Kasus di atas adalah kecurangan dalam ranah sektor publik yang dilakukan oleh Akuntan. Pada kasus akuntan dalam ranah privat, kasus Enron adalah yang paling mengejutkan. Akibat kasus tersebut, hampir bursa saham di seluruh dunia mengalami gejolak, hingga berujung pada anjolknya harga 
pasar saham waktu itu (Tempo, 2002). Selain Enron, kasus yang mengejutkan di 2015 adalah teruangkapnya manipulasi laporan keuangan yang dilakukan oleh Toshiba. Alasan kedua perusahaan besar tersebut melakukan kecurangan hampir serupa, yakni mempertahankan citra perusahaan dengan nilai laba yang ditinggikan, agar investor tetap menaruh ketertarikan pada perusahaan (Simbolon, 2015).

Semenjak era kasus Enron hingga Thosiba sejatinya peneltian yang berfokus pada praktik kecurangan dalam pelaporan keuangan, khususnya dalam bentuk manipulasi laporan keuangan, sudah sangat banyak dilakukan (misalnya: Sofyani dan Pramita, 2014; Sofyani, 2015; Rafinda et al., 2015; Rahma dan Yulianti, 2016; Murphy dan Mayhew, 2012; Mayhew dan Murphy, 2009; Liyanarachchi dan Newdick, 2009; Tsui dan Ferdinand 1996). Fokus tersebut mencakup tindakan apa yang perlu dilakukan dalam mencegah dan mendeteksi kecurangan oleh pembuat laporan keuangan, hingga cara bagaimana memitigasi faktor pendorong praktik kecurangan.

Namun, kebanyakan dari penelitian yang telah dilakukan tersebut lebih menfokuskan pada pendugaan perilaku etis penyusun laporan keuangan (akuntan) dengan menggunakan pendekatan penelitian kuantitatif, sehingga alasan yang dipaparkan ketika suatu dugaan hipotesis terdukung masih bersifat dugaan teoritis, meskipun dikuatkan oleh bukti statistik (Sofyani dan Akbar, 2015). Padahal, alasan utama yang menjadi dasar kenapa seseorang berperilaku belum tentu sebagaimana yang diaumsikan ketika hipotesis dirumuskan. Sayangnya, setelah dugaan dari hipotesis didukung secara statistik, sangat jarang peneliti kemudian melanjutkan analisis ke tahap yang lebih medalam, misalnya wawancara atau observasi. Padahal, wawancara dan observasi dan teknik konfirmasi sejenisnya dapat membantu peneliti untuk menemukan penjelasan tambahan, apakah alasan seseorang dalam berperilaku etis sesuai dengan konteks penelitian, ataukah justru tidak ada kaitannya sama sekali.

Berangkat dari hal tersebut, maka penelitian ini didesain dengan pendekatan yang lebih mengarah kepada ranah kualitatif dengan memasukkan unsur wawancara ringkas kepada para partisipan penelitian mengenai alasan kenapa mereka memutuskan untuk berperilaku tertentu (Braun dan Clarke, 2006). Hasil wawancara ringkas tersebut kemudian dianalisis dengan pendekatan tematik deduktif untuk menemukan intisari alasan dari keberperilakuan seseorang dalam pelaporan keuangan (Sofyani dan Akbar, 2015), dan selanjutnya dapat dikaitkan dengan teori tertentu mengenai alasan yang dijelaskan oleh partisipan penelitian.

Secara teoritis, hasil penelitian ini dapat memberikan penjelasan secara kongkrit atas alasan berperilaku seseorang dalam menghadapi dilema etika saat pelaporan keuangan untuk tujuan tax avoidance. Secara praktis, hasil penelitian ini dapat dijadikan informasi yang berguna bagi para legislator dalam perumusan kebijakan yang berkaitan dengan praktik penyusunan laporan keuangan maupun praktik pendidikan bagi calon akuntan di masa mendatang. Penelitian ini juga diharapkan dapat menjadi amal jariyah peneliti untuk bekal di yaumil akhir kelak (Insya-Allah). 


\section{TELAAH TEORITIS}

\subsection{KECURANGAN PELAPORAN KEUANGAN}

Kecurangan (fraud) dimaknai sebagai perbuatan melawan hukum yang mengandung unsur kesengajaan, niat jahat, penipuan, penyembunyian, dan menyalahgunakan kepercayaan (Tuanakotta, 2013). Kecurangan yang dilakukan oleh seseorang biasanya bertujuan untuk mengambil keuntungan dengan cara yang dilarang yang dapat berupa uang, barang/harta, jasa, tidak membayar jasa, atau memperoleh bisnis (Tuanakotta, 2013). Terdapat tiga hal yang mendorong seseorang untuk melakukan tindak kecurangan yang terkenal dengan istilah fraud triangle yakni: dorongan (pressure), peluang (opportunity), dan rasionalisasi (rationalization). Dorongan merupakan faktor yang menjadi motif atas upaya kecurangan (Tuanakotta, 2013).

Kecurangan yang dilakukan oleh seseorang dapat dipengaruhi oleh faktor eksternal dan internal seseorang itu sendiri (Sofyani dan Pramita, 2014; Murphy dan Mayhew, 2012; Liyanarachchi dan Newdick, 2009; Tsui dan Ferdinand 1996). Association of Certified Fraud Examiner (ACFE) membagi kecurangan menjadi tiga macam yaitu: korupsi (Corruption), penyalahgunaan aset (Asset Misapropriation), dan laporan keuangan yang dimanipulasi (Fraudulent Statements) (Tuanakotta, 2013). Dorongan dapat berasal dari dalam perusahaan atau luar perusahaan. Pemenuhan kewajiban dan kebutuhan perusahaan menjadi dorongan yang paling kuat dalam menggiring perusahaan untuk melakukan kecurangan. Sedangkan dimensi peluang dalam menggiring perusahaan untuk melakukan tindak kecurangan biasanya terjadi akibat kontrol internal yang kurang ketat, sehingga memungkinkan untuk melakukan upaya kecurangan itu sendiri. Adapun rasionalisasi menjadi faktor penting dalam upaya kecurangan. Pengaruh psikologi pelaku kecurangan ini akan mencari-cari pembenaran atas tindakan kecurangan yang dilakukan (Tuanakotta, 2013).

Penelitian terkait isu kecurangan pelaporan keuangan di Indonesia dilakukan oleh beberapa peneliti dengan pendekatan eksperimen (lihat: Sofyani dan Pramita, 2014; Sofyani, 2015; Rafinda et al., 2015; Rahma dan Yulianti, 2016) dan Survei (lihat Thoyibatun, 2009; Fauwzi dan Yuyetta, 2011; Kusumastuti, 2012). Keterbatasan dari beberapa penelitian tersebut adalah karena penelitian dilakukan dengan pendekatan pengujian hipotesis, maka peneliti tidak benar-benar mengetahui alasan kongkrit yang mendasari seseorang melakukan kecurangan dalam pelaporan keuangan. Berdasarkan keterbatasan yang ada tersebut, maka penelitian ini dilakukan dengan pendekatan scenario kasus dilemma etika dalam pelaporan keuangan yang disertai wawancara ringkas pada semua partisipan penelitian mengenai alasan mereka melakukan (tidak melakukan) maniulasi laporan keuangan. Oleh karenanya, maka rumusan masalah yang dibangun pada penelitian ini adalah:

RM: Apa sajakah alasan yang mendasari seseorang untuk melakukan dan tidak melakukan manipulasi laporan keuangan? 


\section{METODE PENELITIAN}

\subsection{TUJUAN DAN DESAIN PENELITIAN}

Tujuan penelitian ini adalah untuk menganalisis dan mengidentifikasi alasan kenapa seseorang mau dan tidak mau melakukan manipulasi pelaporan keuangan. Penelitian ini menjalankan model pendekatan skenario cerita kasus yang diadopsi dari model penelitian eksperimen Liyanarachchi dan Chris Newdick (2009), Sofyani dan Pramita (2014), dan Madein dan Sholihin (2015). Desain penelitian eksperimen dan pengujian hipotesis yang dikembangkan dalam penelitian ini dapat dilihat pada Gambar 1.

\section{Gambar 1. Desain Skenario Kasus}

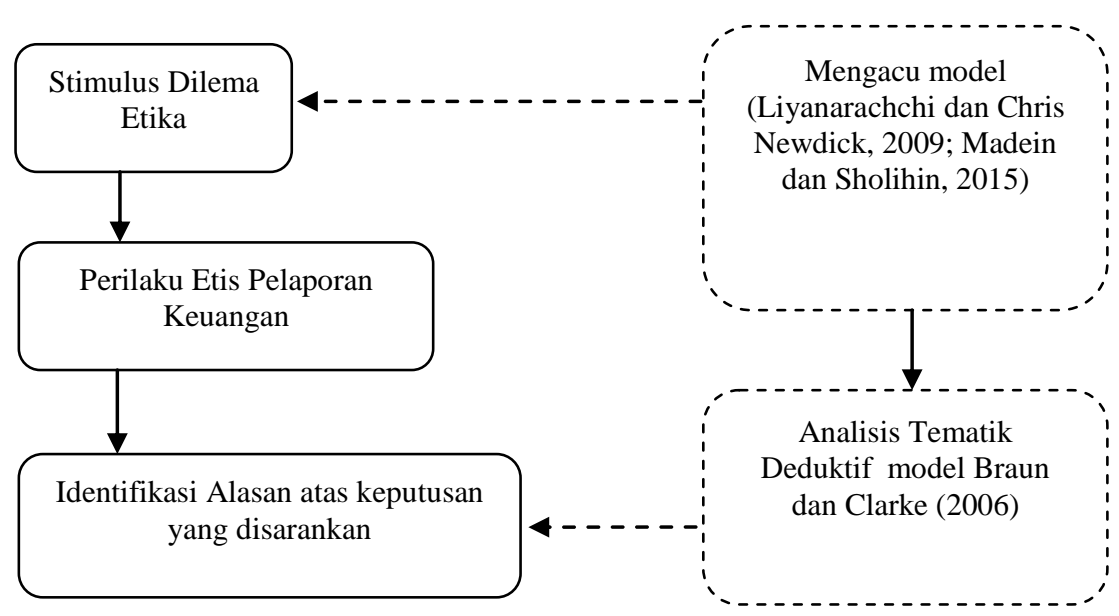

Meskipun menggunakan instrumen dari penelitian eksperimennya Liyanarachchi dan Chris Newdick (2009), Sofyani dan Pramita (2014), dan Madein dan Sholihin (2015), namun pendekatan ini berbeda dengan eksperimen karena tidak terdapat manipulasi dan pengujian hipotesis. Skenario kasus dilema etika pelaporan keuangan yang diajukan kepada partisipan penelitian hanya ditujukan untuk mengetahui justifikasi dari partisipan atas tindakan yang perlu atau sebaiknya dilakukan oleh tokoh yang ada di dalam skenario cerita kasus, apakah melakukan mark up atau tidak.

\subsection{VARIABEL PENELITIAN}

Amatan penelitian ini meliputi perilaku etis seseorang saat pelaporan keuangan dan alasan atas judgment yang mereka buat ketika proses pelaporan keuangan tersebut menghadapi dilema etika. Seknario pelaporan keuangan yang dirumuskan terkait proses penyusunan laporan keuangan rekonsiliasi fiskal untuk tujuan pembayaran pajak perusahaan. Pelaporan etis seseorang saat pelaporan keuangan menggambarkan sikap dan perilaku yang muncul dari individu ketika menghadapi dilema etika. Perilaku etis seseorang saat pelaporan keuangan diukur langsung dengan cara menganalisis hasil jawaban 
responden terkait cerita kasus yang diajukan. Model pengukuran perilaku etis individu dengan pendekatan ini mengacu kepada model penelitian yang dilakukan Liyanarachchi dan Chris Newdick (2009), Sofyani dan Pramita (2014), dan Madein dan Sholihin (2015).

\subsection{PARTISIPAN PENELITIAN DAN KRITERIANYA}

Partisipan penelitian ini adalah mahasiswa program studi Akuntansi di salah satu perguruan tinggi di Yogyakarta yang telah menempuh mata kuliah akuntansi keuangan dan perpajakan. Kriteria partisipan harus yang sudah menempuh dua mata kuliah tersebut agar partisipan memahami skenario yang akan diajukan saat penelitian dilaksanakan, yakni dilema etika saat pelaporan keuangan yang berkaitan dengan perpajakan di suatu perusahaan.

\subsection{PROSEDUR SKENARIO KASUS DILEMA ETIKA}

Sebelum penelitian eksperimen dilakukan, peneliti melakukan cek manipulasi untuk meyakinkan apakah partisipan siap untuk mengikuti skenario kasus dilema etika dalam proses pelaporan keuangan. Cek manipulasi juga meliputi pengecekan terkait pemahaman partisipan mengenai tugas eksperimen yang harus lakukan dan pemahaman terkait hal-hal yang berhubungan dengan penyusunan laporan keuangan dan rekonsiliasi fiskal. Cek manipulasi dilakukan dengan cara menanyai partisipan sebagai berikut(1) Apakah anda memahami proses pelaporan keuangan dan pajak?, (2) Apakah anda memahami apa yang dimaksud dengan rekonsiliasi fiskal dan bagaimana cara melakukannya?, (3) Apakah anda memahami praktik penghindaran pajak (tax avoidance)?.

Partisipan yang tidak memenuhi syarat tidak akan diikutkan dalam skenario kasus dilema etika pelaporan keuangan ini. Selain itu, jika terdapat calon partisipan yang sebelumnya bersedia ikut dalam skenario kasus ini, tetapi datang terlambat juga tidak jadi diikutkan dalam skenario kasus agar jalannya penelitian sesuai dengan rencana peneliti dan tidak mengalami faktor lain yang mungkin akan mengganggu hasil penelitian. Selanjutnya, penelitian dilakukan dengan terlebih dahulu mengacak partisipan ketika masuk ruang skenario kasus dilema etika pelaporan keuangan dan mengacak tempat duduk partisipan dengan tujuan agar faktor-faktor lain yang ada pada diri partisipan tidak berpengaruh pada hasil riset atau terhindar dari bias (Nahartyo, 2012). Setelah itu, partisipan diminta untuk menjawab cerita kasus yang diajukan oleh peneliti dengan waktu yang relatif singkat agar partisipan tidak memiliki kesempatan untuk berdisukusi dengan partisipan lain dalam menjawab instrumen penelitian (Chung dan Trivedi, 2003).

Seluruh partisipan diminta membaca kasus skenario dilema etika dalam bentuk cerita dengan sudut pandang orang ketiga. Partisipan kemudian memberikan saran keputusan atas apa yang dihadapi tokoh di dalam cerita kasus, yakni untuk membuat laporan keuangan dengan melakuikan tax avoidance, yakni menyusun kembali (atau tidak) laporan keuangan yang tidak melanggar peraturan perundang-undangan agar jumlah pajak yang dibayarkan menjadi lebih sedikit dari yang seharusnya, tetapi menjadikan 
kualitas informasi laba perusahaan menjadi lemah. Jawaban partisipan yang dipersepsikan sebagai tokoh dalam cerita kasus tersebut dinilai sebagai perilaku partisipan yang sesungguhnya (Liyanarachchi dan Chris Newdick, 2009; Madein dan Sholihin, 2015). Setelah menjawab, partisipan ditanya alasan mengenai tindakan atau keputusan yang mereka ambil. Hal ini bertujuan untuk menganalisis alasan atas keputusan yang diambil partisipan.

\subsection{IDENTIFIKASI ALASAN DENGAN ANALISIS TEMATIK DEDUKTIF}

Analisis data pada penelitian ini menggunakan analisis tematik deduktif, yakni metoda analitik kualitatif untuk mengidentifikasi, menganalisis dan melaporkan pola atau tema yang terdapat di dalam data (Braun dan Clarke, 2006). Langkah-langkah yang analisis dengan pendekatan inimeliputi: aktivitas pengkodean, pengelompokkan dalam kategori-kategori, penyaringan informasi untuk menemukan ide utama dan mengelompokkannya ke dalam tema-tema yang mengacu kepada teori-teori atau konsep-konsep tertentu, selanjutnya menemukan pola umum dari kecenderungan yang berhasil ditemukan dari data. Dalam analisis tematik tidak diperlukan penjelasan rinci tentang kerangka teori dan pendekatan yang digunakan, akan tetapi untuk membuat menjadi jelas posisi teori tertentu menjadi penting untuk disandarkan (Braun dan Clarke, 2006; Sofyani dan Akbar, 2015). Selain itu, menurut Aronson (1994) analisis tematik juga berfokus pada tema dan pola yang diidentifikasi dalam penelitian. Selanjutnya, dengan menganalisis lebih rinci proses pengkodean, hasil data wawancara yang sudah dipisah-pisah tersebut dapat dihubungkan dengan tema atau masalah penelitian yang sedang dibahas. Terakhir, dilakukan interpretasi data dalam bentuk deskripsi hasil.

Untuk memastikan validitas dari data kualitatif yang sudah terkumpul, maka dilakukan pemeriksaan kembali hasil transkrip untuk memastikan tidak adanya kesalahan yang dibuat selama proses transkripsi. Sedangkan untuk memastikan reliabilitas data maka dilakukan tanya-jawab dengan sesama rekan peneliti (peer de-briefing) untuk meningkatkan keakuratan hasil penelitian (Creswell, 2010).

\section{PEMBAHASAN}

\subsection{GAMBARAN UMUM RESPONDEN}

Penelitian ini dilakukan di salah satu perguruan tinggi di Yogyakarta dengan menggunakan mahasiswa program studi Akuntansi semester enam sebagai subyek penelitian. Mahasiswa yang dipilih menjadi subyek penelitian harus memenuhi kriteria telah menempuh mata kuliah akuntansi keuangan dan perpajakan. Tujuan dibuatnya kriteria tersebut adalah agar mahasiswa memahami proses penyusunan laporan keuangan yang tujuannya untuk pembayaran kewajiban perpajakan oleh suatu perusahaan. Dengan demikian, diharapkan mahasiswa dapat memahami skenario kasus yang akan diajukan 
saat penelitian dilaksanakan, yakni dilema etika saat pelaporan keuangan yang berkaitan dengan perpajakan di suatu perusahaan.

Instrumen yang disediakan dalam penelitian ini adalah sebanyak 300 lembar untuk rencana target 300 partisipan penelitian. Namun, karena bersifat suka rela, maka penelitian ini hanya mendapatkan 90 mahasiswa yang bersedia menjadi partisipan. Dari 90 mahasiswa yang bersedia, ada 6 orang yang dieliminasi karena tidak lulus cek manipulasi, sehingga hanya ada 84 partisipan yang mengikuti jalannya skenario. Dari 84 instrumen tersebut, semuanya dapat dianalisis karena telah diisi dengan benar dan lengkap.

\subsection{JALANNYA SKENARIO}

Sebelum penelitian dilakukan, peneliti melakukan cek manipulasi untuk meyakinkan apakah partisipan siap untuk mengikuti skenario kasus dilema etika dalam proses pelaporan keuangan terkait perpajakan. Cek manipulasi juga meliputi pengecekan terkait pemahaman partisipan mengenai tugas skenario kasus yang harus lakukan dan pemahaman terkait hal-hal yang berhubungan dengan penyusunan laporan keuangan dan rekonsiliasi fiskal. Cek manipulasi dilakukan dengan cara menanyai partisipan sebagai berikut: (1) Apakah anda memahami proses pelaporan keuangan dan pajak?, (2) Apakah anda memahami apa yang dimaksud dengan rekonsiliasi fiskal dan bagaimana cara melakukannya?, (3) Apakah anda memahami praktik penghindaran pajak (tax avoidance)?.

Ketika cek manipulasi dilakukan ditemukan ada 6 (enam) mahasiswa yang tidak dan masih belum mengerti apa yang dimaksud dengan tax avoidance dan proses melakukan rekonsiliasi fiskal. Oleh karenanya, partisipan yang tidak memenuhi syarat tidak akan diikutkan dalam skenario kasus dilema etika pelaporan keuangan ini. Sebelum skenario kasus dijalankan juga ditemukan calon partisipan yang sebelumnya bersedia ikut dalam skenario kasus ini tetapi datang terlambat, sehingga tidak jadi diikutkan dalam skenario kasus agar jalannya penelitian sesuai dengan rencana peneliti dan tidak mengalami faktor lain yang mungkin akan mengganggu hasil penelitian. Setelah semua partisipan menempati tempat duduk yang disediakan, partisipan diminta untuk menjawab cerita kasus yang diajukan oleh peneliti dengan waktu yang relatif singkat agar partisipan tidak memiliki kesempatan untuk berdisukusi dengan partisipan lain dalam menjawab instrumen penelitian (Chung dan Trivedi, 2003; Sofyani dan Pramita, 2014).

\subsection{HASIL JAWABAN PARTISIPAN}

Dari skenario kasus dilema etika saat pelaporan keuangan terkait pembayaran pajak, ditemukan jawaban responden sebagaimana yang disajikan pada Tabel 1. Total partisipan penelitian adalah 84 orang dan dari jumlah tersebut terdapat $61(71,62 \%)$ orang yang menjawab akan melaporkan nilai pajak apa adanya (tidak melakukan tax avoidance) dan ada 23 orang $(27,38 \%)$ yang akan melakukan penyusunan kembali atas laporan keuangan perusahaan, sehingga nilai pajak perusahaan yang dibayarkan akan lebih sedikit dari pada 
yang seharusnya. Dari dua keputusan berbeda tersebut, ditemukan berbagai alasan yang melatarbelakangi kenapa partisipan bersedia melakukan atau tidak melakukan manipulasi laporan keuangan dalam bentuk rekonsiliasi fiskal untuk tujuan tax avoidance.

Tabel 1. Alasan Tidak Melakukan Manipulasi Laporan Keuangan

\begin{tabular}{lcc}
\hline \multicolumn{1}{c}{ Alasan } & Jumlah & $\%^{1}$ \\
\hline Melanggar ajaran agama (termasuk dusta) & 31 & $36.90 \%$ \\
\hline Mempertahankan kejujuran & 17 & $20.24 \%$ \\
\hline Warga negara yang baik dan taat aturan & 13 & $15.48 \%$ \\
\hline Mengharapkan kebaikan dari kejujuran & 10 & $11.90 \%$ \\
\hline Takut diketahui dan mendapatkan sanksi hukuman & 8 & $9.52 \%$ \\
\hline Profesionalisme seorang akuntan & 3 & $3.57 \%$ \\
\hline $\begin{array}{l}\text { Meski tidak diatur secara detail, tetap dinilai melanggar } \\
\text { perundang-undangan }\end{array}$ & 1 & $1.19 \%$ \\
\hline $\begin{array}{l}\text { Selisih laba akuntansi dan setelah rekonsiliasi sangat } \\
\text { besar, jadi dianggap sebagai tax evasion, bukan tax } \\
\text { avoidance }\end{array}$ & 1 & $1.19 \%$ \\
\hline Laki-laki & 19 & $31.15 \%$ \\
\hline Perempuan & 42 & $68.85 \%$ \\
\hline Jumlah & 61 & $100.00 \%$ \\
\hline Total Sampel & $\mathbf{8 4}$ & \\
\hline
\end{tabular}

Sumber: diolah (2016)

\subsubsection{Alasan tidak bersedia melakukan manipulasi laporan keuangan}

Dari tabel 1 dapat disimak bahwa alasan paling dominan dari seseorang tidak mau melakukan manipulasi laporan keuangan adalah karena aktivitas tersebut dinilai melanggar ajaran agama, yakni berlaku dusta. Hal itu ditunjukkan dengan jawaban responden sebanyak 31 orang $(36,90 \%)$ yang memberikan alasan bahwa manipulasi laporan keuangan dengan tujuan tax avoidance akan dimintai pertanggungjawabannya di hari akhirat kelak karena dinilai sama dengan melakukan dusta dalam pembuatan laporan keuangan. Temuan ini sangat menarik karena mengalahkan alasan takut diketahui dan mendapatkan sanksi hukuman yang mendapat respon 8 orang $(9,52 \%)$. Dari jawaban tersebut, secara tidak langsung para responden meyarankan agar pelaporan keuangan diperusahaan oleh akuntan sebaiknya tidak hanya memperhatikan aspek akuntabilitas kepada makhluk, dalam hal ini pemegang kepentingan duniawi (stake-holders), tetapi juga memandang perlunya akuntabilitas Ilahiah (kepada Allah Swt.) disertai dengan keyakinan adanya

\footnotetext{
${ }^{1}$ Prosentase dihitung dari total partisipan yang tidak bersedia melakukan manipulasi laporan keuangan
} 
akuntabilitas dan responsibilitas ukhrawi (Mulawarman, 2009; Triyuwono, 2012; Abdurahim, 2016). Berikut salah satu kutipan jawaban partisipan:

"Sebagai seorang akuntan, seharusnya tokoh yang ada di kasus memikirkan bahwa tindakan yang dilakukannya terkait tax avoidance akan dipertanyakan oleh Allah di hari akhir, meskipun mungkin tidak akan diketahui oleh negara. Perbuatan memanipulasi walau bagaimanapun adalah perbuatan dusta karena tidak menyajikan laporan keuangan apa adanya"

Alasan dari jawaban responden yang mengaitkan manipulasi laporan keuangan dengan penalaran keagamaannya ini sejalan dengan pandangan beberapa peneliti yang menilai bahwa aspek religius dalam diri seseorang akan mampu menjadi penggiring seseorang dalam berperilaku dalam dunia bisnis, khususnya dalam proses penyusunan laporan keuangan (lihat: Sofyani dan Pramita, 2014; Juanda dan Sofyani, 2016; Mayhew dan Murphy, 2009; Fishbein dan Ajzen 1974, 1975; Ajzen dan Fishbein 2005; Mazereeuw et al, 2014). Dalam penjelasan teori perilaku yang direncanakan, Ajzen dan Fishbein (2005) menjelaskan bahwa sikap dalam berperilaku memiliki hubungan dengan keyakinan keberperilakuan (behavioral beliefs) yang dipengaruhi oleh komitmen religius yang diyakini atau dianut oleh seseorang. Sehingga, nilai keagamaan (religioun) merupakan faktor yang dapat menggiring individu dalam bersikap dan berperilaku. Hal ini mengindikasikan bahwa proses pembuatan keputusan etis tidak lepas dari nilai-nilai yang diyakini individu sebelum akhirnya dia berada pada tahap akhir, yakni pelaksanaan aksi perilaku etis ketika menghadapi dilema etika (rahma dan Yulianti, 2016).

Dalam pandangan Islam, seorang muslim harus masuk ke dalam Islam (agama yang dianutnya) secara kaffah (menyeluruh) -tidak parsial- mencakup aspek keyakinan (akidah), hukum dan ibadah (syariah) dan akhlak (perilakutermasuk etika di dalamnya) (Abdurahim, 2016). Ke-kaffah-an seseorang yang mencakup akhlak dijelaskan dalam salah satu ayat Alqur'an (QSAlmu'minun [23], ayat: 8), bahwa dijelaskan bahwa seorang Mu'min (orang yang kuat dan teguh keimanannya) adalah orang yang senantiasa menjaga amanah.

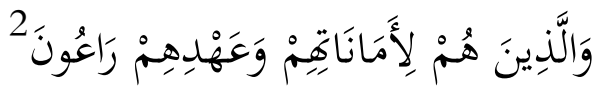

Artinya:

Dan orang-orang yang memelihara amanat-amanat (yang dipikulnya) dan janjinya.

\footnotetext{
${ }^{2}$ Dalam sir Jalalayn dijelaskan bahwa makna ayat ini adalah: Dan orang-orang yang terhadap amanat yang dipercayakan kepada mereka) dapat dibaca secara jamak dan mufrad, yakni Amaanaatihim dan Amaanatihim (dan janji mereka) yang mereka adakan di antara sesama mereka atau antara mereka dengan Allah, seperti salat dan lain-lainnya (mereka memeliharanya) benar-benar menjaganya (al-Mahalliy, J., \& Suyūṭ̂̄, 1990).
} 
Dari ayat di atas, jika dikaitkan dalam konteks dunia akuntansi, akuntan (pajak) adalah seseorang yang diamanahi untuk menghitung dan melaporkan keuangan suatu entitas, dimana hasil perhitungan dan pelaporannya ini akan digunakan oleh banyak orang dalam pengambilan keputusan yang bersifat ekonomi. Dengan demikian, jika seorang akuntan melakukan hal yang bertentangan dengan etika (akhlak), maka berarti akuntans tersebut tidak menjaga keimanannya. Maka sebaliknya, orang yang menjaga keimanan, maka akan menjaga amanah pekerjaannya agar sesuai dengan ajaran agama yang dianutnya.

Selanjutnya, alasan menjaga kejujuran menempati mayoritas kedua dari jawaban partisipan bagi seseorang untuk tidak bersedia melakukan manipulasi laporan keuangan. Berangkat dari temuan ini, maka upaya untuk membentuk pribadi akuntan yang jujur menjadi sangat penting dan krusial. Jika kita kaitkan dengan kasus-kasus akuntansi seperti Enron, Toshiba, WorldCom dan lainnya, maka semuanya memiliki kesamaan sebab, yakni tidak jujurnya akuntan dalam melaksanakan tugasnya, baik sebagai penyusun laporan keuangan (akuntan internal) maupun ketika memeriksa laporan keuangan (akuntan eksternal). Dengan demikian, isu mengenai bagaimana pola pendidikan karakter yang tepat bagi para akuntan, menjadi isu penelitian yang masih harus terus digali. Jika merujuk pada perkembangan dunia akuntansi dewasa ini, dalam konteks pendidikan akuntan, masih terfokus pada pendidikan komptensi profesional, khususnya pengetahuan. Sementara, aspek karakteristik individu berbudi luhur dari para akuntan masih minim mendapat perhatian (Juanda dan Sofyani, 2016). Bahkan, keberadaan pendidikan etika di kurikulum pendidikan akuntansi dipandang hanya sebatas mata kuliah pelengkap. Setiawan (2016) menemukan Kode Eetik Ikatan Akuntan Indonesia (IAI) masih banyak tidak memuat nilai-nilai pancasila yang sarat dengan budi luhur. Itu artinya, dalam ranah regulasi kode etik akuntan Indonesia saja, aspek karakter individu akuntan yang berkaitan dengan nilai-nilai nusantara masih mendapat perhatian yang minim. Berikut salah satu kutipan jawaban partisipan:

“... sebaiknya tokoh (di dalam skenario kasus) mempertahankan kejujurannya... selain itu, tokoh itu juga harus yakin bahwa kejujuran akan mendatangkan kebaikan. Bisa jadi di amsa mendatang dia akan mendapatkan sesuatu yang lebih bernilai buah dari kejujurannya."

Berikutnya, temuan yang sangat menarik lainnya adalah alasan takut diketahui dan mendapatkan sanksi hukuman hanya dijawab oleh 8 orang $(9,52 \%)$ dan tidak menjadi alasan paling mayoritas. Ini atinya, alasan seseorang mempertahankan integritasnya dalam menyusun laporan keuangan tidak didominasi oleh ketakutan akan hukuman atau ancaman, tetapi masih dominan dari aspek religiusitas dan kesadaran, setidaknya dalam konteks penelitan ini. Hasil ini menunjukkan bahwa orang Indonesia (yang diwakili oleh sampel ini dengan segala keterbatsannya) masih memprioritaskan aspek kesadaran moral yang berdasar pada ajaran agama dan nilai-nilai luhur nusantara. Dari dalam diri mayoritas partisipan ditemukan masih banyaknya nilai-nilai fondasi berperilaku yang didasarkan pada kebaikan yang 
bersumber dari kesadaran nilai yang dianut ketimbang ancaman sanksi yang dimunculkan agar suatu tindakan buruk dijauhi. Dengan demikian, berangkat dari temuan ini maka penanaman kesadaran moral lebih dominan untuk menggiring sesorang dalam bertindak etis ketimbang keberadaan hukuman. Dari sini, maka penanaman kesadaran moral ini sangat penting dibangun, khususnya sejak seseorang masih kecil. Hal ini sangat sejalan dengan temuan lain dimana alasan kedua meyoritas dari seseorang bertahan dengan ntegritas saat pelaporan keuangan adalah penjunjungan yang tinggi pada nilai luhur kejujuran. Berikut salah satu kutipan jawaban partisipan:

"sebaiknya tokoh menghindari malkukan manipulasi laporan keuangan. Hal itu dikhawatirkan akan diketahui oleh negara dan yang bersangkutan akan mendapatkan sanksi hukuman denda bahkan penjara. Selain itu, orang lain akan menilai tokoh menjadi orang yang tidak jujur. Sehingga, dia akan mengalami kesusahan di amsa mendatang."

\subsubsection{Alasan bersedia melakukan manipulasi laporan keuangan}

Dari temuan dimana partisipan bersedia melakukan manipulasi laporan keuangan dalam proses perhitungan pajak dengan tujuan tax avoidance (lihat Tabel 2), alasan utamanya adalah karena hal itu tidak diatur dalam peraturan perundang-undangan, sehingga hal itu dianggap sah dan boleh dilakukan. Responden yang menjawab dengan alasan demikian ada sebanyak 18 orang $(64,29 \%)$.

Hasil ini konsisten dengan berbagai penelitian dan pandangan yang menjelaskan bahwa karena tax avoidance dinilai tidak diatur dalam perundang-undangan, maka upaya yang dilakukan oleh perusahaan dalam meminimalisir nilai pajaknya dengan cara membuat maipulasi laporan keuangan untuk tujuan tax avoidance dianggap sah dan boleh dilakukan. Temuan ini juga sejalan dengan pandangan konsep fraud triangle yang dipaparkan di atas, dimana ketika ada celah, maka seseorang akan terdorong untuk melakukan tindak kecurangan, dalam hal ini adalah celah UndangUndang. Selanjutnya, ketika seseorang melakukan kecurangan, seseorang tersebut akan mencari rasionalitas untuk membenarkan tindaknya yang dilakukan tersebut (Tuankotta, 2013).

Selanjutnya, terdapat temuan yang sangat menarik dari penelitian ini, yakni adanya partisipan yang beralasan bahwa manipulasi laporan keuangan untuk tujuan tax avoidance ini boleh dilakukan agar (tokoh dalam skenario kasus) mendapatkan bonus dari perusahaan. Temuan ini cukup mengejutkan karena jumlah yang menjawab demikian ada 5 orang $(17,86 \%)$. Temuan ini membenarkan konsep yang menjelaskan bahwa terdapat motif self interest pada diri seseorang yang menggiring untuk memenuhi self interest-nya itu dengan memanfaatkan situasi dimana terjadi asimetri informasi (Irfan et al. 2015). 
Tabel 2. Alasan Melakukan Manipulasi Laporan Keuangan

\begin{tabular}{lcc}
\hline \multicolumn{1}{c}{ Alasan } & Jumlah & $\%^{\mathbf{3}}$ \\
\hline $\begin{array}{l}\text { Dianggap sebagai sesuatu yang dapat diterima karena } \\
\text { tidak melanggar undang-undang }\end{array}$ & 18 & $64.29 \%$ \\
\hline Mengharap mendapatkan bonus/insentif & 5 & $17.86 \%$ \\
\hline Risiko dipecat & 2 & $7.14 \%$ \\
\hline Diperlukan untuk meningkatkan laba & 1 & $3.57 \%$ \\
\hline $\begin{array}{l}\text { Karena perusahaan melakukan CSR sehingga boleh } \\
\text { mengurangi pajak }\end{array}$ & 1 & $3.57 \%$ \\
\hline Boleh kalau nilainya tidak dianggap besar & 1 & $3.57 \%$ \\
\hline Jumlah & 28 & $100.00 \%$ \\
\hline Laki-laki & 13 & $56.52 \%$ \\
\hline Perempuan & 10 & $43.48 \%$ \\
\hline Jumlah & 23 & $100.00 \%$ \\
\hline Total Sampel & 84 & \\
\hline
\end{tabular}

Selain itu, ada pula yang beralasan bahwa manipulasi laporan keuangan untuk tujuan tax avoidance perlu dilakukan untuk meningkatkan laba (riil) perusahaan. Pandangan ini serupa dengan alasan yang menyatakan bahwa manipulasi laporan keuangan untuk tujuan tax avoidance sah dilakukan karena perusahaan melakukan CSR sehingga boleh mengurangi pajak. Temuan ini mengindikasikan bahwa aktivitas sosial (CSR) merupakan beban bagi perusahaan yang dapat mengurangi laba. Dengan demikian, sebagai kompensasinya, maka upaya untuk menjaga laba perusahaan, salah satunya dengan aktivitas tax avoidance menjadi hal yang diperbolehkan. Dua pandangan ini sangat kental adanya paradigma kapitalisme dimana tujuan utama dari perusahaan adalah mendapatkan laba yang sebesar-besarnya demi kemakmuran orang-orang internal perusahaan, yakni pengelola dan pemilik entitas (lihat: Mulawarman, 2009; Triyuwono, 2012; Abdurahim, 2016). Hal ini juga mengindikasikan bahwa adanya paradigma kapitalisme pada diri seseorang menjadikan orang tersebut mulai berniat untuk menghalalkan sesuatu yang dilarang demi memperoleh laba. Meskipun yang menjawab dengan argumentasi seperti ini hanya satu orang, tetapi hal ini mengindikasikan bahwa ternyata paradigma kapitalisme ini memang ada dan tertanam di pola pikir seseorang, bahkan di saat orang tersebut masih berstatus mahasiswa.

\footnotetext{
keuangan

${ }^{3}$ Prosentase dihitung dari total partisipan yang bersedia melakukan manipulasi laporan
} 


\section{SIMPULAN}

Penelitian ini bertujuan untuk mengidentifikasi alasan kenapa seseorang mau dan tidak mau melakukan manipulasi laporan keuangan. Penelitian ini menggunakan desain skenario dilema etika yang dikembangkan oleh Sofyani dan Pramita (2014). Sampel pada penelitian ini adalah mahasiswa program studi akuntansi di salah satu perguruan tinggi di Yogyakarta yang telah menempuh mata kuliah akuntansi keuangan dan perpajakan. Analisis data dilakukan dengan pendekatan tematik deduktif (Braun dan Clarke, 2006). Penelitian menemukan bahwa mayoritas orang yang mau melakukan manipulasi laporan keuangan dikarenakan manipulasi laporan keuangan untuk tujuan tax avoidance dianggap tidak melanggar peraturan perundangundangan atau hal yang dilanggar tidak ada aturannya di dalam perundangundangan. Sementara mayoritas orang yang menolak melakukan manipulasi laporan keuangan beralasan bahwa hal itu melanggar ajaran agama, karena terdapat unsur dusta.

Dari temuan penelitian yang dipaparkan, maka penting bagi akuntan untuk mendapatkan pendidikan karakter yang berkaitan dengan penanaman nilai religius dan nilai-nilai bermuatan moral lainnya, seperti nilai budi luhur yang ada pada budaya Nusantara agar dapat menjadikan akuntan yang lebih etis dan jujur. Selain itu, adanya celah perundang-undangan memicu manipulasi laporan keuangan untuk tujuan tax avoidance menjadi kerap dilakukan oleh akuntan yang mengetahui celah tersebut. berangkat dari temuan ini, maka penting kiranya untuk dilakukan pengetatan standar dalam peraturan akuntansi perpajakan guna memitigasi praktik rekonsiliasi fiskal laporan keuangan yang mengarah pada praktik manipulasi laporan keuangan untuk menghindari pajak (tax evasion).

Penelitian ini memiliki keterbatasan, yaitu lingkup penelitian masih sempit, yakni hanya di satu perguruan tinggi di Yogyakarta, sehingga kemampuan generalisasi dari hasil penelitian ini lemah. Untuk itu penelitian selanjutnya dapat dilakukan di tempat lain. Hasil penelitian ini juga dapat dijadikan dasar pengembangan untuk penelitian selanjutnya dengan cakupan yang lebih luas, misalnya dengan pendekatan riset survei. Selanjutnya, penelitian ini menggunakan sampel mahasiswa yang sebaiknya pada peneltiannya selanjutnya benar-benar menggunakan sampel akuntan. Penggunaan mahasiswa memang masih menuai perdebatan, walaupun beberapa peneliti menilai hal itu tidak menjadi masalah karena aspek yang diteliti adalah perilaku dan psikologis partisipan dan bukan profesi dari partisipan merupakan akuntan atau mahasiswa akuntansi (Nahartyo, 2012). Terakhir, penelitian selanjutnya dapat menjalankan pendekatan penelitian campuran agar dapat menemukan gambaran fenomena yang lebih komprehensip dibandingkan dengan hanya menggunakan satu pendekatan saja (Sofyani dan Akbar, 2013; 2015). 


\section{DAFTAR PUSTAKA}

al-Mahalliy, J., \& Suyūṭī. (1990). Terjemah tafsir jalalain berikut asbaabun nuzul. Sinar Baru.

Abdurahim, A. 2016. Aminullah: Revealing the Spiritual Values in Sharia Transaction. International Journal of Management and Administrative Sciences, Vol. 4, No. 1, 65-73.

Ajzen, I and Fishbein, M. 2005. The Influence of Attitudes on Behaviour. In B. Albarracin, T. Jhonson, dan M.P. Zanna (eds.). The Handbook of Attitudes. Mawah: Erlbaum, 2005.

Aronson, J. (1995). A pragmatic view of thematic analysis. The qualitative report, 2(1), 1-3.

Chung, J., \& Trivedi, V. U. (2003). The effect of friendly persuasion and gender on tax comliance behavior. Journal of Business Ethics, 47(2), 133-145.

Creswell, J. W. (2010). Research Design: Qualitative, Quantitative and Mixed Methods Approaches . California: Sage Publication.

Fauwzi, M. dan Yuyetta, E. N. A. (2011). Analisis Pengaruh Keefektifan Pengendalian Internal, Persepsi Kesesuaian Kompensasi, Moralitas Manajemen terhadap Perilaku Tidak Etis dan Kecenderungan Kecurangan Akuntansi. Doctoral dissertation, Universitas Diponegoro.

Fishbein, M., dan I. Ajzen. 1974. Attitudes towards objects as predictors of single and multiple behavioral criteria. Psychological Review, 81 (1), 59-74.

Fishbein, M., dan I. Ajzen. 1975. Belief, attitude, intention, and behavior: An introduction to theory and research. Reading: Addison-Wesley.

Irfan, M., Santoso, B., \& Effendi, L. (2016). Pengaruh Partisipasi Anggaran terhadap Senjangan Anggaran dengan Asimetri Informasi, Penekanan Anggaran dan Komitmen Organisasional sebagai Variabel Pemoderasi. Jurnal Akuntansi dan Investasi, 17(2), 158-175.

Juanda dan Sofyani, H. (2016). Konsep Pendidikan Karakter Keagamaan Untuk Calon Akuntan: Studi Kasus di Program Studi Akuntansi Universitas Muhammadiyah Yogyakarta. Jurnal Akuntansi dan Investasi, 17 (2), 186-196.

Kusumastuti, N. R., \& Meiranto, W. (2012). Analisis Faktor-Faktor yang Berpengaruh terhadap Kecenderungan Kecurangan Akuntansi dengan Perilaku Tidak Etis Sebagai Variabel Intervening. Doctoral dissertation, Universitas Diponegoro. 
Liyanarachchi, G. And N. Chris. 2009. The Impact of Moral Reasoning and Retaliation on Whistle-Blowing: New Zealand Evidence. Journal of Business Ethics, 89, 37-57.

Madein, A., dan M. Sholihin. 2015. The impact of social and environmental information on managers' decisions: Experimental evidence from Indonesia. Asian Review of Accounting, 23 (2), 156-169.

Majalah Akuntan Indonesia. 2015. Akuntan Penyebab Krisis?. http://iaiglobal.or.id/v03/majalah-akuntan/arsip. Diakses 20 November 2016.

Mazereeuw, C., J. Graafland dan M. Kaptein. 2014. Religiosity, CSR Attitudes, and CSR Behaviour: An Empirical Study of Executives' Religiosity and CSR. Journal of Business Ethics, 123, 437-459.

Mayhew, B. W. dan Murphy, P. R. 2009. The Impact of Ethics Education on Reporting Behavior. Journal of Business Ethics, Vol.86, No.3, pp.397416.

Mulawarman, A. D. (2009). Akuntansi Syariah: Teori, Konsep dan Laporan Keuangan. Penerbit e-publishing. Jakarta.

Murphy, P. R., dan B. W. Mayhew. 2012. The Impact of Authority on Reporting Behavior. SSRN Electronic Journal, (Electronic copy available at: http://ssrn.com/abstract=2026449). Diakses 20 November 2016.

Rafinda, A., Arofah, T., Mustafa, R. M., dan Ompusunggu, H. (2015). Does an ethic matter to predict misreporting behavior?. Journal of Economics, Business, and Accountancy| Ventura, 18(1), 133-144.

Setiawan, A.R. 2016. Mempertanyakan Nilai-Nilai Pancasila pada Profesi Akuntan: Bercermin pada Kode Etik IAI (Ikatan Akuntan Indonesia). Jurnal Ilmiah Akuntansi, 1 (1).

Simbolon, H. A. 2015. Toshiba Accounting Scandal: Runtuhnya Etika Bangsa Jepang Yang Sangat Diagungkan Itu. https://akuntansiterapan.com/2015/07/22/toshiba-accounting-scandalruntuhnya-etika-bangsa-jepang-yang-sangat-diagungkan-itu/. Diakses 20 November 2016.

Sofyani, H., \& Akbar, R. (2013). Hubungan Faktor Internal Institusi dan Implementasi Sistem Akuntabilitas Kinerja Instansi Pemerintah (SAKIP) di Pemerintah Daerah. Jurnal Akuntansi dan Keuangan Indonesia, 10(2), 184-205.

Sofyani, H dan Y. D. Pramita. 2014. Otoritas Atasan, Retaliasi dan Locus of Control Sebagai Faktor-Faktor yang Memengaruhi Perilaku Manipulasi Laporan Realisasi Anggaran. Jurnal Reviu Akuntansi dan Keuangan, 3 (2), 415-506. 
Sofyani. 2016. Dapatkah Pendidikan Karakter Keagamaan Memitigasi Perilaku Tidak Etis Akuntan?. Paper Dipresentasikan di Simposium Nasional Akuntansi Syariah, Surakarta.

Sofyani, H. dan R. Akbar. 2015. Hubungan Karakteristik Pegawai Pemerintah Daerah Dan Implementasi Sistem Pengukuran Kinerja: Perspektif Ismorfisma Institusional. Jurnal Akuntansi \& Auditing Indonesia, Vol. 19 No.2, Hlm. 153-173.

Thoyibatun, S. (2009). Faktor-faktor yang berpengaruh terhadap perilaku tidak etis dan kecenderungan kecurangan akuntansi serta akibatnya terhadap kinerja organisasi. Jurnal Ekonomi dan Keuangan, 16, 245260 .

Triyuwono, I. 2012. Akuntansi Syariah; Perspektif, Metodologi, dan Teori. Edisi Kedua. Jakarta: Rajawali Press.

Tsui, Judy S L. \& Ferdinand A Gul. (1996). Auditors' Behaviour In An Audit Conflict Situation: A Research Note On The Role Of Locus Of Control And Ethical Reasoning. Accounting, Organizations and Society, 21 (1), 41-51.

Tuanakotta, T. M. 2013. Audit Berbasis ISA (International Standards on Auditing). Salemba Empat. Jakarta. 